\title{
Innovative Activity in the Caribbean: Drivers, Benefits, and Obstacles
}

\section{Preeya Mohan, Eric Strobl, and Patrick Watson}

Innovation has long been associated with productivity growth in that, hypothetically, it results in more effective use of a firm's resources and improved productivity. There is ample empirical evidence that firms that engage in innovation-type activities-such as spending on research and development (R\&D) and obtaining intellectual property rights through patents and copyrights-are more technologically advanced and have higher labor productivity, enabling them to compete better internationally (Schumpeter 1939; Griliches 1986; Freeman 1994; Griffith et al. 2006; Mairesse and Mohnen 2010). Furthermore, there is evidence that investment in innovation-type activities results in sustainable long-run growth and development (Hall and Jones 1999; OECD 2009; Rouvinen 2002).

In view of the potential benefits, policymakers in the Caribbean have acknowledged the role that innovation may play in increasing productivity, as well as economic growth and development. For instance, in 1988,

\section{P. Mohan $(\bowtie) \bullet$ P. Watson}

Sir Arthur Lewis Institute of Social and Economic Studies (SALISES),

University of the West Indies

email: Preeya.Mohan@sta.uwi.edu•

patrick.watson@sta.uwi.edu

E. Strobl

Ecole Polytechnique

email: eric.strobl@polytechnique.edu

(C) Inter-American Development Bank 2016

M. Grazzi and C. Pietrobelli (eds.), Firm Innovation

and Productivity in Latin America and the Caribbean,

DOI 10.1057/978-1-349-58151-1_3 
the Caribbean Community Secretariat (CARICOM) adopted a regional science and technology policy (Nurse 2007); in 2000, it established the Caribbean Council for Science and Technology to coordinate and implement this policy; and, in 2007, it formulated a regional framework for action (Nurse 2007). More recently, Jamaica's National Council for Science and Technology (NCST) introduced a strategic plan entitled "Science and Technology for Socio-Economic Development: A Policy for Jamaica" for 2005-2010, using foresighting techniques to develop a five-year master strategy and implementation plan for information communication technologies (ICTs) called "E-Powering Jamaica 2012" (NCST 2005). In other countries in the region, while there are institutions responsible for establishing and implementing national innovation systems, for the most part no formal strategic plans exist.

It is not clear how much benefit will accrue to the Caribbean because of innovation, largely because there is a paucity of studies on innovation and its impact on productivity in small island developing states like those in the Caribbean. The few studies tend to group the Caribbean with Latin America, and findings suggest that innovation and productivity are quite low and, indeed, constrain growth (Lederman et al. 2014; Ortiz et al. 2012; Daude and Fernández-Arias 2010; IDB 2010). Further, we note that most of these studies use spending on R\&D to measure innovation activity though, as argued by Crespi and Zuñiga (2012), in developing countries the link between innovation and productivity is not well established since imitation and technology acquisition may play a more important role than R\&D investment.

In this chapter we examine the impact of innovation on firm productivity in the Caribbean, hoping to fill existing gaps in the literature. We use cross-sectional firm-level data for the manufacturing sector from the World Bank Enterprise Surveys (WBES) for 14 Caribbean countries. Using non- and semi-parametric tests, and a set of productivity measures, we find evidence that innovative firms exhibit higher productivity than non-innovative firms. To identify any causal effect of innovation on productivity, we follow Crespi and Zuñiga (2012) and Griffith et al. (2006) and use a structural recursive model that takes into account firms' decision to invest in innovative activities rather than simply R\&D expenditures. This approach models a knowledge-production function based on how much knowledge output is generated from the innovation investment, then estimates an output-production function in which labor productivity is determined by innovative activity together with other inputs. In using this approach, we experiment with other measures of productivity. 
The next section of this chapter provides a brief overview of the literature on the productivity effects of innovative activities. Then we describe the data we used in our study, followed by non- and semi-parametric tests of productivity differences between innovative and non-innovative firms. We next outline our econometric model, and then present and discuss the results of our estimations. We then provide conclusions.

\section{Literature REVIEW}

Traditionally, a firm's R\&D expenditures were considered a direct determinant of innovation activity and increased productivity. Moreover, since data on the amount firms spend on R\&D are widely and readily available (they are routinely recorded by firms), they are a convenient proxy to measure innovation activity. It is generally assumed that the more a firm spends on R\&D the more innovative it is. In other words, increased R\&D expenditures help boost process and product innovation by reducing the production cost of existing goods and helping increase the number of new goods produced. The relationship between innovation and productivity can then be modeled using a knowledge-production function, and the contribution of innovation to productivity measured using an outputproduction function, where the production of new knowledge is determined by the amount firms spent on R\&D (Griliches 1979; Griliches and Pakes 1980; Cohen and Levinthal 1989).

Crépon et al. (1998) were the first to investigate the relationship between innovation and productivity with innovation inputs measured using the R\&D expenditures of French manufacturing firms. The CDM model is a system of recursive equations linking a firm's R\&D expenditures to its innovation output which, in turn, is linked to productivity. Their findings provided evidence that firm productivity increased with higher innovation as measured by R\&D investment. Further, they showed that $\mathrm{R} \& \mathrm{D}$ spending increased with firm size, market share, diversification, and demand-pull and technology-push forces.

Later studies by Hall and Mairesse (2006) and Mairesse and Mohnen (2010) confirmed the results obtained by Crépon et al. (1998) but emphasized the importance of firm heterogeneity in explaining innovation activities and the need to control for their effects on firm performance in empirical work. Further, the correlation between product innovation and productivity is often higher for larger firms (Griffith et al. 2006; OECD 2009) and, in most countries, the productivity effect of product innovation is larger in the manufacturing sector than in the services sector 
(OECD 2009). These studies showed that, in developed countries, the more a firm spent on $\mathrm{R} \& \mathrm{D}$, the more likely it was to be innovative when controlling for firm characteristics such as size, market, and diversification.

The empirical evidence on innovation and productivity in developing countries is, however, not as straightforward. For instance, a positive relationship between $\mathrm{R} \& \mathrm{D}$, innovation, and productivity has been found in newly industrialized Asian countries (Lee and Kang 2007; Hegde and Shapira 2007; Aw et al. 2008; Jefferson et al. 2006 and some Latin American countries (Chudnovsky et al. 2006; Arza and Lópezez 2010; Correa et al. 2005), but other studies in Latin America found no significant relationship (Raffo et al. 2008; Pérez et al. 2005; Chudnovsky et al. 2006; Hall and Mairesse 2006). The failure of R\&D expenditure to correlate positively with innovation and productivity may be explained by the fact that firms in developing countries are too far from the technological frontier and that incentives to invest in innovation are weak or absent (Acemoglu et al. 2006). Moreover, in developing countries, R\&D costs are high and may require a longer time to produce results (Navarro et al. 2010).

Later studies identified several weaknesses in using R\&D expenditures alone to measure innovation. First, not all R\&D expenditures necessarily lead to successful innovation and productivity growth: rather, they are simply an input into the innovation process and not a measure of innovation output. Using R\&D, therefore, does not prove how successful a firm is at introducing new and improved products and services or production processes.

Second, innovation is a multi-dimensional and complex process, and R\&D expenditures is but one component of innovation expenses. R\&D expenditures alone, therefore, may not accurately measure innovation and may, on the contrary, be an underestimation of the true cost of innovation, which may include financing product design and training. In a study of German manufacturing firms, Felder et al. (1996) highlighted the importance of non-R\&D innovation expenditures. Calvo (2003), in a study of Spanish manufacturing firms, found that more than half of the innovative firms did not spend on R\&D.

It is clear, therefore, that approximating innovation using $\mathrm{R} \& \mathrm{D}$ expenditures may underestimate a firm's innovative capacity. More recently, innovation surveys provide data for studies that introduce a broader set of variables to measure innovative activity. In this regard, Griffith et al. (2006) and Crespi and Zuñiga (2012) extended the recursive system approach developed by Crépon et al. (1998) to incorporate broader measures of innovation. More precisely, they took into account firms' decisions to invest in innovative activity rather than simply R\&D expenditures, along with other inputs related 
to labor productivity, in creating the knowledge-production function from which the output-production function was then created. A firm's innovation decision then included any action that aimed to increase its knowledge, such as new concepts, ideas, processes, and methods. This included R\&D expenditures, but also other expenditures, such as product design, marketing, staff training, new machinery, patents, and other trademark licensing.

The model used by Griffith et al. (2006) and Crespi and Zuñiga (2012) was also different because it distinguished between process and product innovation by estimating them separately, since there is likely to be a high collinearity between these factors as the majority of the firms undertook both simultaneously. Empirically, it is hard to separate product and process innovation, which results in identification problems when using the two variables in the productivity equation. In addition to firm characteristics, the model also included external forces that affected a firm's innovation decision, such as: demand-driven innovation, including environmental, health, and safety regulation; technological-push innovation (scientific opportunities); and innovation policy. Ultimately, their frameworks also allowed selectivity bias and endogeneity in the innovation and productivity function to be controlled in the same manner as the original CDM framework. We use a similar approach in this study.

\section{Data and Descriptive Analysis}

\section{Data}

We use data from the WBES, which consists of firm-level surveys of a representative sample of an economy's private sector. The surveys cover a wide range of topics and are not limited to innovation, technology, and performance measures. ${ }^{1}$ Private contractors administer the surveys face-toface with business owners and top managers. The stratification factors are firm size, business sector, and geographic region within a country. These data provide rich firm-level data on 2771 firms from 14 Caribbean countries, all interviewed in 2010 (see Table 3.1). Unfortunately, the innovation module of the 2010 surveys was limited to manufacturing firms, thus limiting our analysis to that sector.

\section{Descriptive Analysis}

Table 3.1 shows the number of firms interviewed in each country: the number ranges from 376 (Jamaica) to 150 (Bahamas, Barbados, Belize, 
Table 3.1 Summary statistics, WBES data

\begin{tabular}{llcccc}
\hline Country & ISO code & $\begin{array}{l}\text { No. of } \\
\text { firms }\end{array}$ & $\begin{array}{l}\text { No. of innovative } \\
\text { firms }\end{array}$ & $\begin{array}{l}\text { No. of firms } \\
\text { (sample) }\end{array}$ & $\begin{array}{l}\text { No. innovative } \\
\text { firms (sample) }\end{array}$ \\
\hline Antigua and Barbuda & ATG & 151 & 8 & 29 & 5 \\
Bahamas & BHS & 150 & 12 & 35 & 11 \\
Barbados & BRB & 150 & 27 & 64 & 20 \\
Belize & BLZ & 150 & 15 & 69 & 14 \\
Dominica & DMA & 150 & 4 & 23 & 1 \\
Dominican Republic & DOM & 350 & 81 & 109 & 42 \\
Grenada & GRD & 153 & 7 & 22 & 7 \\
Guyana & GUY & 165 & 35 & 59 & 27 \\
Jamaica & JAM & 376 & 62 & 105 & 23 \\
St. Kitts \& Nevis & KNA & 150 & 10 & 23 & 6 \\
Saint Lucia & LCA & 150 & 7 & 56 & 6 \\
St. Vincent \& the & VCT & 154 & 15 & 45 & 11 \\
Grenadines & & & & & 12 \\
Suriname & SUR & 152 & 12 & 102 & 16 \\
Trinidad and Tobago & TTO & 370 & 20 & $\mathbf{8 1 4}$ & $\mathbf{2 0 1}$ \\
\hline Total & & $\mathbf{2 7 7 1}$ & $\mathbf{3 1 5}$ &
\end{tabular}

Source: Authors' calculations based on WBES data

Note: All surveys were conducted in 2010

Dominica, St. Kitts \& Nevis, and Saint Lucia). Among the 2771 firms interviewed, only 315 are innovative. The country with the largest number of innovative firms is the Dominican Republic (81 firms) and the country with the lowest is Dominica (four firms). Moreover, there is considerable variation in ownership (foreign versus domestic), export activity, size, and industry (manufacturing versus services). The left side of Table 3.2 provides the percentage of all firms interviewed by country, broken down by descriptive categories. As seen, the majority of firms interviewed are domestic, non-exporting, small service providers. Very importantly, therefore, we are missing information on innovative activity for a large proportion of Caribbean firms. In contrast, Table 3.3 displays the percentage of innovative manufacturing firms in each country, broken down by descriptive categories. Innovative firms in the Caribbean are domestic, medium-sized manufacturers, and about half export.

We also examine innovation by type of activity. Table 3.4 shows that innovation expenditures in Caribbean manufacturing occurs mainly through R\&D expenditures: $8 \%$ of firms in the region are innovative on 
Table 3.2 Innovation activity (\%)

\begin{tabular}{|c|c|c|c|c|c|c|}
\hline & $\begin{array}{l}\text { Research and } \\
\text { development }\end{array}$ & $\begin{array}{l}\text { Cooperate on } \\
\text { innovation }\end{array}$ & $\begin{array}{l}\text { Receive } \\
\text { public } \\
\text { support for } \\
\text { innovation }\end{array}$ & $\begin{array}{l}\text { Patents } \\
\text { abroad }\end{array}$ & $\begin{array}{l}\text { Patents } \\
\text { locally }\end{array}$ & $\begin{array}{l}\text { Purchases of } \\
\text { licenses for } \\
\text { intellectual } \\
\text { property }\end{array}$ \\
\hline $\begin{array}{l}\text { Antigua and } \\
\text { Barbuda }\end{array}$ & 5 & 0 & 1 & 0 & 0 & 2 \\
\hline Bahamas & 8 & 3 & 0 & 0 & 0 & 6 \\
\hline Barbados & 18 & 5 & 6 & 0 & 0 & 6 \\
\hline Belize & 4 & 1 & 0 & 0 & 0 & 10 \\
\hline Dominica & 2 & 0 & 0 & 0 & 0 & 3 \\
\hline $\begin{array}{l}\text { Dominican } \\
\text { Republic }\end{array}$ & 11 & 10 & 4 & 8 & 23 & 13 \\
\hline Grenada & 5 & 3 & 1 & 0 & 0 & 3 \\
\hline Guyana & 21 & 16 & 2 & 0 & 0 & 7 \\
\hline Jamaica & 9 & 5 & 1 & 7 & 16 & 7 \\
\hline $\begin{array}{l}\text { St. Kitts \& } \\
\text { Nevis }\end{array}$ & 7 & 5 & 1 & 0 & 0 & 1 \\
\hline Saint Lucia & 5 & 0 & 0 & 0 & 0 & 2 \\
\hline $\begin{array}{l}\text { St. Vincent \& } \\
\text { the Grenadines }\end{array}$ & 10 & 6 & 3 & 0 & 0 & 3 \\
\hline Suriname & 2 & 5 & 3 & 0 & 0 & 8 \\
\hline $\begin{array}{l}\text { Trinidad and } \\
\text { Tobago }\end{array}$ & 5 & 4 & 0.2 & 2 & 5 & 3 \\
\hline Total & 8 & 5 & 2 & 2 & 6 & 6 \\
\hline
\end{tabular}

Source: Authors' calculations based on WBES data

the basis of R\&D spending, followed by $6 \%$ of firms that innovate through local patents and license purchases of intellectual property. Furthermore, only $2 \%$ of firms innovate through public support and patents abroad. The country with the highest percentage of firms spending on R\&D and cooperating on innovation is Guyana, followed by Barbados and the Dominican Republic. Barbados, however, has the highest percentage of firms that receive public support for innovation (6\%) while, in many other countries, firms receive very little or none (Bahamas, Belize, Dominica, Saint Lucia, and Trinidad and Tobago).

In Table 3.5, innovative activity in manufacturing is broken down by type of innovation (product or process). Product occurs more frequently than process innovation: $15 \%$ of firms in the region introduced new or improved products, while only $9 \%$ introduced new or improved processes. Suriname has the largest percentage of firms undertaking product 
Table 3.3 Product versus process innovation (\%)

\begin{tabular}{|c|c|c|c|c|}
\hline & $\begin{array}{l}\text { New/significantly } \\
\text { improved products } \\
\text { introduced }\end{array}$ & $\begin{array}{l}\text { New/significantly } \\
\text { improved products } \\
\text { new to establishment } \\
\text { market }\end{array}$ & $\begin{array}{l}\text { New/significantly } \\
\text { improved process for } \\
\text { producing/supplying } \\
\text { products }\end{array}$ & $\begin{array}{l}\text { New/significantly } \\
\text { improved processes } \\
\text { also new to your } \\
\text { industry }\end{array}$ \\
\hline $\begin{array}{l}\text { Antigua and } \\
\text { Barbuda }\end{array}$ & 7 & 1 & 1 & 0 \\
\hline Bahamas & 17 & 12 & 7 & 3 \\
\hline Barbados & 28 & 16 & 16 & 9 \\
\hline Belize & 14 & 3 & 3 & 2 \\
\hline Dominica & 3 & 0 & 0 & 0 \\
\hline $\begin{array}{l}\text { Dominican } \\
\text { Republic }\end{array}$ & 17 & 10 & 14 & 8 \\
\hline Grenada & 11 & 7 & 5 & 3 \\
\hline Guyana & 17 & 12 & 22 & 9 \\
\hline Jamaica & 12 & 6 & 9 & 5 \\
\hline $\begin{array}{l}\text { St. Kitts \& } \\
\text { Nevis }\end{array}$ & 9 & 6 & 5 & 3 \\
\hline Saint Lucia & 7 & 0 & 1 & 0 \\
\hline $\begin{array}{l}\text { St. Vincent } \\
\text { \& the } \\
\text { Grenadines }\end{array}$ & 15 & 10 & 13 & 9 \\
\hline Suriname & 34 & 16 & 7 & 1 \\
\hline $\begin{array}{l}\text { Trinidad and } \\
\text { Tobago }\end{array}$ & 15 & 5 & 9 & 4 \\
\hline Total & 15 & 7 & 9 & 4 \\
\hline
\end{tabular}

Source: Authors' calculations based on WBES data

innovation (34\%), followed by Barbados, the Bahamas, the Dominican Republic, and Guyana. Countries with the lowest percentage of firms undertaking product innovation are Dominica (3\%), Saint Lucia (7\%), and St. Kitts \& Nevis (9\%). Guyana has the highest percentage of firms undertaking process innovation (22\%) followed by Barbados and Suriname $(16 \%)$, while countries with the lowest percentage are Dominica $(0 \%)$, Antigua and Barbuda, and Saint Lucia (1\%).

\section{Non and Semi-Parametric Analysis of Productivity DifFERENCES}

All of the variables used in this section are listed in Table 3.6. Since the techniques we use do not accommodate missing values, the sample size is substantially reduced, to 814 firms. The country and innovation 
Table 3.4 Summary statistics, regression variables

\begin{tabular}{lcllll}
\hline & Mean & $\begin{array}{l}\text { Standard } \\
\text { deviation }\end{array}$ & Mean & $\begin{array}{l}\text { Standard } \\
\text { deviation }\end{array}$ & $\begin{array}{c}\text { Difference- } \\
\text { in-means test }\end{array}$ \\
\cline { 2 - 5 } & INNOV=I & INNOV=1 & INNOV=0 & INNOV=0 \\
\hline TFP (stochastic) & 12.3 & 1.6 & 12.5 & 1.5 & $6.21^{* * *}$ \\
TFP (deterministic) & 12.4 & 1.7 & 12.5 & 1.6 & $6.97^{* * *}$ \\
Labor productivity & 1.8 & 0.7 & 1.6 & 0.7 & $4.17^{* * *}$ \\
Firm size & 12.6 & 1.5 & 12 & 1.4 & $5.78^{* * *}$ \\
Public finance & 0.1 & 0.3 & 0.02 & 0.2 & $3.34^{* * *}$ \\
Patent protection & 0.2 & 0.3 & 0.05 & 0.1 & $2.67^{* * *}$ \\
Exporter & 0.4 & 0.5 & 0.2 & 0.4 & $6.36^{* * *}$ \\
Cooperation & 0.3 & 0.5 & 0.1 & 0.3 & $8.74^{* * *}$ \\
Foreign ownership & 0.2 & 0.4 & 0.2 & 0.4 & $2.59^{* * *}$
\end{tabular}

Source: Authors' calculations based on WBES data

Notes: ${ }^{*}$ Coefficient is statistically significant at the $10 \%$ level, ** at the $5 \%$ level, *** at the $1 \%$ level; no asterisk means the coefficient is not different from zero with statistical significance. Difference-in-means test reports the $\mathrm{t}$-statistic. TFP $=$ total factor productivity

Table 3.5 Kolmogorov-Smirnov test of productivity, innovative versus non-innovative

\begin{tabular}{lll}
\hline Productivity measure & $F=G$ & $F \leq G$ \\
\hline Stochastic TFP & $0.267 * * *$ & 0.000 \\
Deterministic TFP & $0.265^{* * *}$ & 0.000 \\
Labor productivity & $0.148^{* * *}$ & 0.020 \\
\hline
\end{tabular}

Source: Authors' calculations based on WBES data

Notes: ${ }^{*}$ Coefficient is statistically significant at the $10 \%$ level, **at the $5 \%$ level, $* * *$ at the $1 \%$ level; no asterisk means the coefficient is not different from zero with statistical significance. $\mathrm{F}$ is the distribution of the innovative and $\mathrm{G}$ the distribution of the non-innovative firms

breakdown of these firms is shown in Table 3.1 and, while the country breakdown remains relatively unaffected, the percentage of innovative firms appearing in the reduced sample is about 5 percentage points larger than the corresponding figure in the total sample.

Employing both non- and semi-parametric methods, we determine whether firms investing in innovation in the Caribbean are indeed more productive than non-innovative firms. ${ }^{2}$ The latter group does not spend any funds on R\&D or technological innovation activities. 
Table 3.6 Probability of investing in innovation (ID) and intensity of innovation expenditure per employee (IE)

\begin{tabular}{ll}
\hline ID (probability of investing in innovation IE $>0)$ & \\
\hline Exporter & $0.1320^{* * *}$ \\
Foreign ownership & $(0.0370)$ \\
& 0.0100 \\
Patent protection & $(0.0350)$ \\
Firm size & 0.0080 \\
& $(0.0480)$ \\
\hline IE (log innovation expenditure per employee) & $0.0340^{* * *}$ \\
\hline Exporter & $(0.0090)$ \\
& \\
Foreign ownership & $-0.8530^{* * *}$ \\
Patent protection & $(0.3020)$ \\
& -0.1820 \\
Cooperation & $(0.3350)$ \\
& 0.1590 \\
Public finance & $(0.4560)$ \\
& 0.3840 \\
\hline Observations & $(0.2500)$ \\
Wald test & 0.4380 \\
Wald test of independence $(\rho=0)$ & $(0.4260)$ \\
Log pseudo likelihood & 812 \\
\end{tabular}

Source: Author's calculations based on WBES data

Notes: Coefficients reported are marginal effects.

* Coefficient is statistically significant at the $10 \%$ level, ** at the $5 \%$ level, $* * *$ at the $1 \%$ level

\section{Non-Parametric Test}

The simplest measure of productivity available from our data is labor productivity. The difference-in-means test, shown in Table 3.7, confirms that, in the Caribbean, the mean value of labor productivity for innovative firms is larger than that of non-innovative firms. Non-parametric kernel density graphs of each firm type's labor productivity distribution, shown in Fig. 3.1, provide evidence that innovative firms are also characterized by more productivity dispersion than their non-innovative counterparts. 
Table 3.7 Probability of technological innovation (TI: introduction of product or process innovation)

\begin{tabular}{ll}
\hline IE_p (predicted innovation & $0.557^{* * *}$ \\
expenditure per employee) & $(0.119)$ \\
Firm size & $0.045^{* * *}$ \\
& $(0.016)$ \\
Exporter & $0.477^{* * *}$ \\
& $(0.075)$ \\
Foreign ownership & $0.178^{* * *}$ \\
& $(0.055)$ \\
\hline Observations & 812 \\
Wald test & $151.69^{* * *}$ \\
Log psuedo likelihood & -476.63 \\
Psuedo R & 0.153 \\
Observed probability & 0.502 \\
Predicted probability (values at means) & 0.506
\end{tabular}

Source: Authors' calculations based on WBES data

Notes: Coefficients reported are marginal effects. Robust standard errors in parentheses.

${ }^{*}$ Coefficient is statistically significant at the $10 \%$ level; ** at the $5 \%$ level; *** at the $1 \%$ level

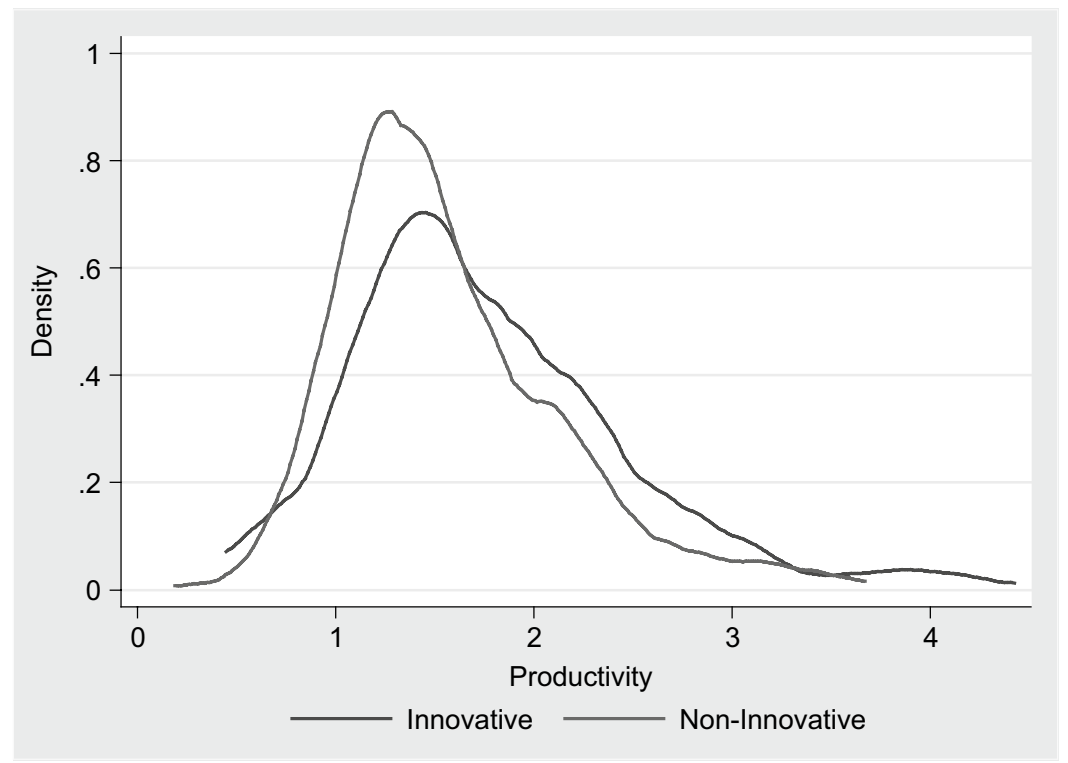

Fig. 3.1 Productivity distribution—labor productivity Source: Authors' calculations based on WBES data 
To test differences across firm types by taking into account moments of order higher than 2, we resort to the concept of first-order stochastic dominance. More precisely, let $F$ be the cumulative distribution of innovative and $G$ be the same for non-innovative firms' productivity (prod). First-order stochastic dominance is defined as $F($ prod $)-G($ prod $)$ uniformly in $\operatorname{prod} \in \mathfrak{R}$, with strict equality for some. In contrast to a means test, firstorder stochastic dominance thus considers all moments of the productivity distribution of firms.

We use the non-parametric one-sided and two-sided KolmogorovSmirnov tests (Delgado et al. 2002) to establish or refute first-order stochastic dominance of the productivity of innovative firms over noninnovative firms. The two-sided test investigates the hypothesis that both the innovative and non-innovative firms' productivity distributions are identical. The null $\left(\mathrm{H}_{0}\right)$ and alternative $\left(\mathrm{H}_{1}\right)$ hypotheses are:

$$
\begin{aligned}
& H_{0}: F(\operatorname{prod})-G(\operatorname{prod})=0 \forall \operatorname{prod} \in \\
& H_{1}: F(\operatorname{prod})-G(\operatorname{prod}) \neq 0 \text { for some } \operatorname{prod} \in
\end{aligned}
$$

In contrast, the null and alternative hypotheses of the one-sided test of first-order stochastic dominance are:

$$
\begin{aligned}
& H_{0}: F(\operatorname{prod})-G(\operatorname{prod}) \leq 0 \forall \operatorname{prod} \in \\
& H_{1}: F(\text { prod })-G(\operatorname{prod})>0 \text { for some } \operatorname{prod} \in \mathfrak{R}
\end{aligned}
$$

In order to conclude that the distribution of innovative firms, $F$, dominates that of non-innovative firms, $G$, we need to reject the null hypothesis for the two-sided test but not for the one-sided test.

The Kolmogorov-Smirnov test statistics for the one-sided (equation 3.1) and two-sided (equation 3.3) tests are:

$$
\begin{gathered}
K S_{1}=\sqrt{\frac{n \cdot m}{N} \max _{1 \leq i \leq N}\left|F_{n}\left(\operatorname{prod}_{i}\right)-G_{m}\left(\operatorname{prod}_{i}\right)\right|} \\
K S_{2}=\sqrt{\frac{n \cdot m}{N} \max _{1 \leq i \leq N}\left\{F_{n}\left(\operatorname{prod}_{i}\right)-G_{m}\left(\operatorname{prod}_{i}\right)\right\}}
\end{gathered}
$$


Table 3.8 The impact of innovation on labor productivity (Y: log sales per employee)

\begin{tabular}{lc} 
IE_p (predicted innovation expenditure per employee) & $0.625^{* * *}$ \\
& $(0.243)$ \\
Firm size & 0.019 \\
& $(0.021)$ \\
Non-technological innovation & $0.266^{* *}$ \\
& $(0.127)$ \\
Capital per employee & 0.006 \\
& $(0.073)$ \\
\hline Observations & 812 \\
Wald test & $346.470^{* * *}$ \\
$R^{2}$ & 0.314
\end{tabular}

Source: Authors' calculations based on WBES data

Notes: Bootstrapped standard errors in parentheses (100 replications). The variable used as a proxy for physical capital is investment made during the period considered the stock of physical capital

${ }^{*}$ Coefficient is statistically significant at the $10 \%$ level, ${ }^{* *}$ at the $5 \%$ level, $* * *$ at the $1 \%$ level

where $n$ and $m$ are the sample sizes from the empirical distributions of $F$ and $G$, respectively, and their sum is $N$. We report the KolmogorovSmirnov statistic for the one- and two-sided tests for labor productivity in Table 3.8. The test statistics provide evidence that labor productivity in innovating firms stochastically dominates productivity in non-innovative firms. Thus, innovative firms in the Caribbean exhibit higher productivity across all moments of the distribution, not just around the mean.

\section{Semi-Parametric Test}

The non-parametric test has the advantage that it does not require any (possibly restrictive) distributional assumptions. On the other hand, it does not allow the investigator to account for the possibility that innovative firms may differ from non-innovative firms in characteristics that are correlated with productivity. For instance, a cursory glance at the difference-in-means of the control variables across firm type in Table 3.7 
shows that non-innovative firms are smaller, are less likely to obtain public financial support for innovation, are less likely to have patents, are less likely to export, are less likely to cooperate with other firms or institutions in terms of innovative activity, and are less likely to be foreign-owned. Thus, conclusions about the relationship between productivity and innovation spending, based on non-parametric testing, may be, at least in part, driven by differences in other firm characteristics.

To account for differences in characteristics when comparing distributions, DiNardo et al. (1996) developed an approach that allows for graphical assessment of the difference in distributions of an outcome variable of interest between two groups by disentangling what is due to differences in characteristics and what remains unexplained. In essence, their approach is a semi-parametric method based on the construction of counterfactual densities obtained by reweighting observations according to differences in the underlying characteristics. In our context, this means calculating the distribution of productivity of non-innovative firms if they had the characteristics of innovative firms. More specifically, each individual observation may be considered a vector (PROD, $Z$, $I N N O V)$, where $Z$ is the vector of firm attributes other than innovation that are correlated with productivity. The joint distribution of productivity and characteristics conditional on innovation status may be defined as $F(P R O D, Z \mid I N N O V=0,1)$. The density of productivity for innovative firms, $f_{I N N O V=0,1}(P R O D)$, may then be expressed as the integral of the density of productivity, conditional on some firm characteristics and on innovative activity, $f(P R O D \mid Z, I N N O V=0)$, over the distribution of firm characteristics $F(Z \mid I N N O V=1)$ :

$$
f(P R O D ; I N N O V=0,1)=\int_{Z} d F(P R O D, Z \mid I N N O V=0,1)
$$

where the set of productivities comes from innovative firms and the set of characteristics from non-innovative firms. In like manner, the counterfactual for $Z$ from innovative firms, $f\left(P R O D\right.$; $\left.P R O D_{I N N O V=0}, Z_{I N N O V=1}\right)$, may be expressed in terms of reweighting the actual distribution as:

$$
\begin{aligned}
& f\left(P R O D ; P R O D_{I N N O V=0}, Z_{I N N O V=1}\right) \\
& \left.=\int_{Z} f\left(P R O D \mid Z, P R O D_{I N N O V=0}\right) \Psi_{Z}(Z) d F(Z \mid I N N O V=1)\right)
\end{aligned}
$$


where

$$
\begin{aligned}
\Psi(Z) & =\frac{d F(Z \mid I N N O V=1)}{d F(Z \mid I N N O V=0)} \\
& =\frac{\operatorname{Pr} o b\left(Z_{I N N O V=1} \mid Z\right) \operatorname{Pr} o b(I N N O V=0)}{\operatorname{Pr} o b\left(Z_{I N N O V=0} \mid Z\right) \operatorname{Pr} o b(I N N O V=1)}
\end{aligned}
$$

To estimate this counterfactual, the weight $\Psi_{Z}(Z)$ (i.e. the probability of being innovative or not given firms' characteristics $Z$ ) is estimated using logit or probit methods, which predicts the probability $\operatorname{Prob}(I N N O V=1 \mid Z)$ and $\operatorname{Prob}(I N N O V=0 \mid Z)$ for each firm in the sample.

We employ the DiNardo et al. (1996) method to explore distributional differences in labor productivity between innovating and noninnovating firms using a firm's export status, foreign ownership, patent possession, government support, size, non-technological innovation, and innovation cooperation status as other productivity determinants. We estimate equation 3.6 using the probit model. ${ }^{3}$ In Fig. 3.2, we depict the

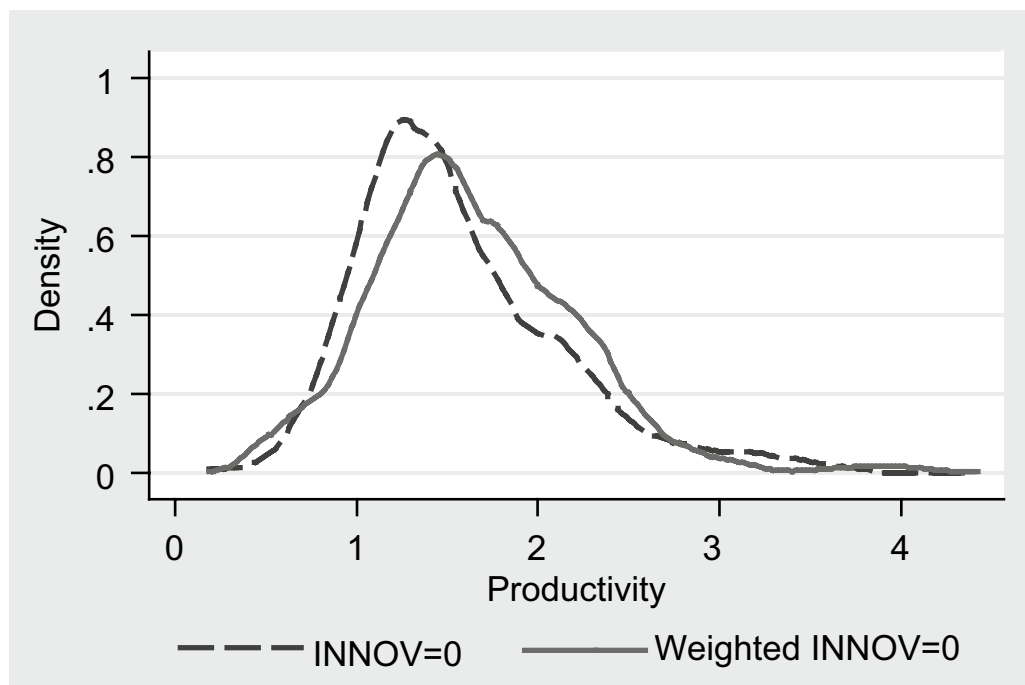

Fig. 3.2 Non-innovative and weighted non-innovative firms-labor productivity Source: Authors' calculations based on WBES data 


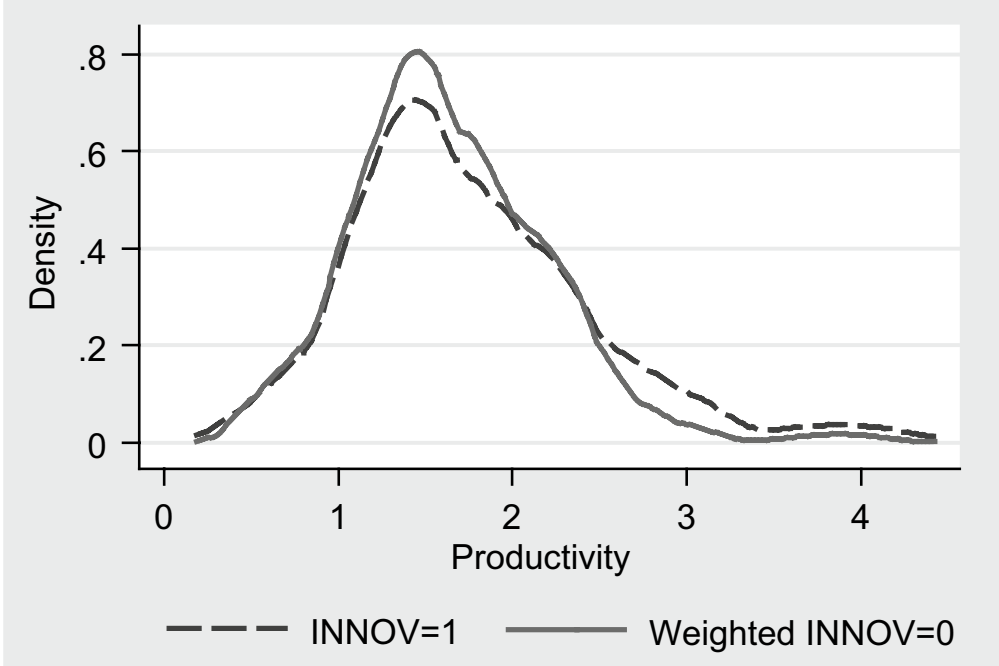

Fig. 3.3 Innovative and weighted non-innovative firms-labor productivity Source: Authors' calculations based on WBES data

counterfactual distribution of equation 3.5, the distribution of productivity of non-innovative firms but with innovative firm type characteristics relative to their true distribution. Accordingly, the counterfactual has a higher mean and higher dispersion, implying that, if non-innovative firms were similar in characteristics to innovative firms, they would have higher mean productivity as well as greater inequality in productivity across that group.

In Fig. 3.3, we compare the counterfactual non-innovative firm productivity distribution to the true innovative firm productivity distribution. Relative to the raw difference in distribution, these graphs show that the difference in distributions in labor productivity between innovative and non-innovative firms is less marked. This implies that some non-negligible part of the difference in the distributions of productivity between the two types of firms was due to differences in their other characteristics. Moreover, the counterfactual non-innovative distribution also appears to be somewhat closer to that of the innovative firms rather than that of the actual non-innovative distribution, suggesting that differences between innovative and non-innovative firms are due more to differences in characteristics than to being innovative. Nevertheless, it remains clear that, even 
after adjusting for differences in characteristics, non-innovative firms have a lower mean and more dispersion in productivity than innovative firms.

\section{Alternative Productivity Measures}

Thus far we have focused simply on labor productivity as a measure of a firm's efficiency. However, the data also allow us to obtain, relatively simply, more sophisticated measures of productivity. As a starting point, we assume that there is some efficient production frontier where output is at its maximum and where a firm, if it is operating at that frontier, is regarded as technically efficient. Consider, for example, a firm with a Cobb-Douglas production function with two inputs, labor $(L)$ and capital $(K)$ :

$$
Y_{i}=A_{i} K_{i}^{\beta_{k}} L_{i}^{\beta_{L}}
$$

Given that A is unobservable, it is estimated. In natural logarithms, an empirical equivalent of equation 3.7 is:

$$
y_{i}=\beta_{0}+\beta_{k} k+\beta_{l} l+\varepsilon_{i}
$$

where $\beta_{0}$ measures the mean efficiency across firms and $\varepsilon$ is the producerspecific deviation from that mean, which can be further decomposed into observable (i.e. predictable) and unobservable components:

$$
y_{i}=\beta_{0}+\beta_{k} k+\beta_{l} l+v_{i}+u_{i}
$$

where firm-level productivity is just $\beta_{0}+v_{i}$, which can easily be estimated with data on a firm's output, capital stock, and labor using simple regression analysis.

The logic underlying this one-sided error component specification is that differences in firm productivity are due to differences in management ability, and thus any firm not operating at the frontier is less efficiently managed. However, more realistically, sometimes maximum output itself may be higher or lower due to exogenous shocks, meaning the frontier may be different across firms. Moreover, not all firms share a common family of production, cost, and profit functions, and thus some measurement error will inevitably be introduced in estimating productivity from equation 3.11. Aigner et al. (1977) extended the deterministic frontier analysis 
approach to allow for these factors. More specifically, they assumed that $u_{i}$ can be decomposed as:

$$
u_{i}=\pi_{i}+\eta_{i}
$$

where $\pi$ is the symmetric disturbance from the frontier and $\eta<0$ is the true error component, which is assumed to be distributed independently of $\pi$. The normally distributed $\pi$ captures the possibility that the frontier may vary for each firm due to measurement errors and uncertainty regarding external events, and not necessarily due to managerial inefficiency. Aigner et al. (1977) demonstrated how incorporating equation 3.11 into equation 3.12 can be estimated using maximum likelihood methods.

Both the deterministic and stochastic frontier-derived productivities for all firms are estimated using equations 3.10 and 3.11., 5 The mean and standard deviation for these alternative productivity measures are shown in Table 3.7. As is the case with the labor productivity results, average productivity is higher for innovative firms for these proxies as well, which is confirmed by a simple difference-in-means test. ${ }^{6}$

In order to check for robustness we computed the raw distributions, and the difference is even more pronounced for the two total factor productivity (TFP) measures than for simple labor productivity (details available from the authors). The relevant Kolmogorov-Smirnov test statistic is shown in Table 3.8. Again, the conclusion holds: innovative firms exhibit higher productivity across all moments of the distribution. Similarly, the conclusions with regard to the semi-parametric distributional method also hold, meaning the non-negligible part of the difference in the distributions of productivity between the two types of firms appears to be due to differences in their other characteristics. Differences between innovative and non-innovative firms are due more to differences in characteristics than to being innovative, although the latter aspect appears to be less so for the two TFP measures than for labor productivity.

\section{ECONOMETRIC MODEL}

The non- and semi-parametric tests suggest that firms that spend on innovation are more productive than ones that do not, even after controlling for differences in characteristics. However, this does not imply causality. 
Moreover, given the dichotomous nature of these tests, we can only focus on whether a firm spends money or not, not how much it spends. In order to gain further insight into causality and amount of spending, we follow Crespi and Zuñiga (2012) and explicitly model the innovative decision process to determine its causal impact on productivity.

In their analysis of the impact of innovation on productivity in several Latin American countries, Crespi and Zuñiga (2012) extended the structural recursive model of Crépon et al. (1998) as follows. Let $i=1, \ldots ., N$ represent an index of firms. The first equation of the model accounts for the firm's innovative effort $I E_{i}^{*}$ :

$$
I E_{i}^{*}=z i^{\prime} \beta+e_{i}
$$

where $I E_{i}^{*}$ is an unobserved latent variable and is measured by the log of expenditures on innovation activities divided by the number of employees, $\mathrm{z}_{i}$ is a vector of determinants of the firm's innovation decision, $\beta$ is a vector of parameters, and $e_{i}$ is the error term.

A firm's decision to undertake innovative activity is then modeled as follows:

$$
\begin{aligned}
I D_{i} & =\operatorname{lif} I D_{i}^{*}=w_{i}^{\prime} \alpha+e_{i}>c \\
& =0 \text { if } I D_{i}^{*}=w_{i}^{\prime} \alpha+e_{i} \leq c
\end{aligned}
$$

where $I D_{i}$ is a binary endogenous variable equal to 1 if the firm invests in innovative activity above a certain threshold level $c$, and 0 if it does not; $w$ is a vector of variables explaining the innovation investment decision; $\alpha$ is a vector of parameters of interest; and $e_{i}$ is an error term.

Conditional on firm $i$ engaging in innovation activities, we can observe the amount of resources invested in innovation (IE) activities:

$$
\begin{aligned}
& I E_{i}=I E_{i}^{*}=z_{i}^{\prime} \beta+\varepsilon_{i} \text { if } I D_{i}=1 \\
& \quad 0 \text { if } D_{i}=0
\end{aligned}
$$

Assuming the error terms $e$ and $\varepsilon$ are bivariate normal with zero mean and variances, respectively, $\sigma_{\varepsilon}{ }^{2}=1$ and $\sigma_{\mathrm{e}}{ }^{2}$ and correlation coefficient $\rho_{\varepsilon \varepsilon}$, the system of equations 3.14 and 3.15 can be viewed as a generalized Tobit model, estimable by maximum likelihood. 
To model the knowledge/innovation production function, consider:

$$
T I_{i}=I E_{i}^{*} \gamma+x_{i}^{\prime} \delta+u_{i}
$$

where $T I_{i}$ is knowledge outputs by technological innovation (introduction of a new product or process at the firm level) and the latent innovation effort, $I E$, enters as an explanatory variable, $x$ is a vector of other determinants of knowledge production, $\gamma$ and $\delta$ are vectors of parameters of interest, and $u$ is an error term.

The final equation of the model sets out the relationship between innovation and labor productivity. Firms produce output using constant returns to scale with labor, capital, and knowledge inputs as follows:

$$
y_{i}=\theta_{i} k_{i}+\theta_{2} T I_{i}+v_{i}
$$

where output $y$ is labor productivity ( $\log$ of sales per worker), $k$ is the log of physical capital per worker (measured as physical investment per worker), and TI enters as an explanatory variable that refers to the impact of technological innovation on productivity levels.

To estimate the full set of equations, we use a three-step estimation procedure since the model does not allow for feedback effects. First, we estimate the generalized Tobit model in equations 3.14 and 3.15. Next, we estimate the innovation function in equation 3.16 using a probit model, where the predicted value of $(\log )$ innovation expenditures is the main explanatory variable rather than reporting innovation efforts. Importantly, this corrects for potential endogeneity in the knowledgeproduction equation. Finally, we estimate the productivity equation using the predicted values from the second step to take care of the endogeneity of $T I_{i}$ in equation 3.16 .

Given the small sample sizes of individual countries, data across countries are pooled prior to applying the Crespi and Zuñiga (2012) procedure. In this regard, we control for unobserved country characteristics as well as sector differences by including a full set of two-digit ISIC code and country dummies in all specifications. The remaining explanatory variables are in line with Crespi and Zuñiga (2012), except for their controls "the importance of market sources of information," "scientific sources of information," and "public sources of information." We eliminate these controls because there are too many missing values for these variables in 
the dataset. The model is estimated for all firms - not for innovative firms only-since most surveys do not have a filter and most of the questions are asked of all firms. Also, the model assumes that all firms exert some kind of innovative effort, but not all report this activity. The output of these efforts produces knowledge, and we can then estimate innovation efforts for all firms.

\section{Econometric Results}

\section{The Decision to Invest in Innovation and the Intensity of Innovation Expenditures}

Table 3.9 presents the results for the estimation of equations 3.14 and 3.15 , which specify the determinants of the likelihood to engage in innovation activities within the firm and the intensity of these expenditures (log of innovation expenditure per worker) for the Caribbean. The reported estimates are the marginal effects of the generalized Tobit model. The identification of our model rests on the assumption that firm size affects the decision to invest but not how much a firm will invest (Crespi and Zuñiga 2012).

The results show that firms that export and those that are larger are more likely to invest in innovation, while having patent protection or foreign ownership does not significantly predict the decision to invest in innovation. The effect of the "size" variable is not surprising given that it is generally believed that there are economies to scope resulting from investing in innovation (Cohen and Levinthal 1989). Similarly, the finding that exporting firms are more likely to invest is expected, as this is consistent with the findings of Aw et al. (2008) that the decision to export and the decision to invest in $\mathrm{R} \& \mathrm{D}$ are intrinsically linked. The insignificance of "foreign ownership" may signal that foreign firms are using Caribbean countries as an outlet for their products rather than as a testing ground to improve production.

In terms of the size of the coefficients, an exporting firm is $13 \%$ more likely to invest in innovation, while a one unit increase in logged employment increases the probability of investment by 3.4 percentage points. With regard to the latter, for example, the largest firm in our estimation sample is nearly $50 \%$ more likely to invest in innovation than the smallest firm, all else being equal. Crespi and Zuñiga (2012) also found that "exporting" is a significant predictor of innovation expenditures in Argentina, Chile, and 


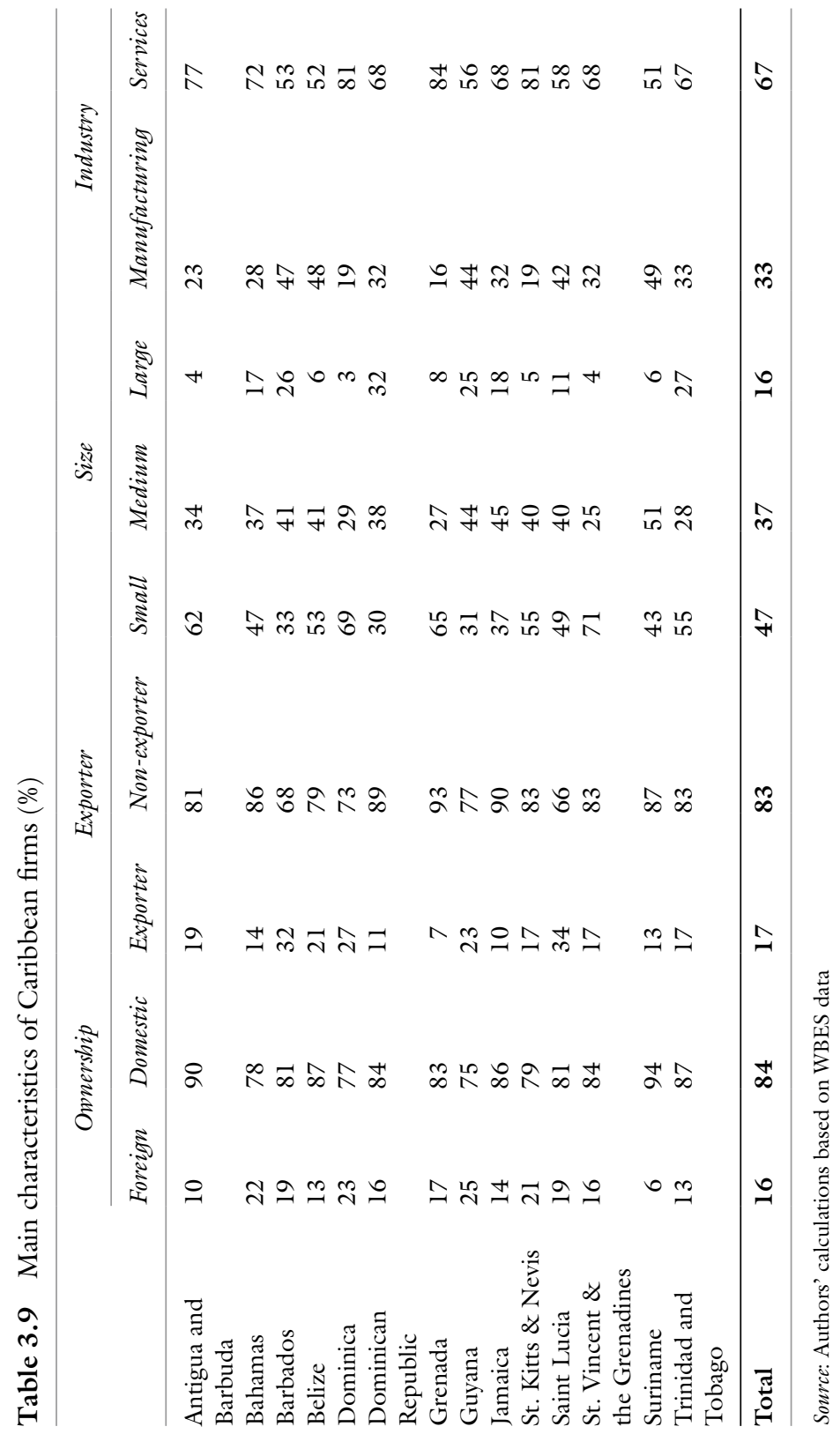


Columbia. Our results are similar in size to those of Crespi and Zuñiga (2012) for Argentina and Chile but larger for Colombia. Our result for employment is also similar to the Crespi and Zuñiga results for all countries in their study, although for none of these was the coefficient smaller than 0.08. Thus, in the Caribbean, size seems to be a better predictor of a firm's willingness to invest in innovation. In contrast to our results, foreign ownership did not seem to matter in Crespi and Zuñiga's (2012) Latin American sample, except Argentina, and patent protection was important for all countries, again except Argentina. The fact that patent protection does not matter in our results suggests that it is less credible and/or less effective in the Caribbean compared to Latin America (see Chap. 2). Only the "exporter" variable is significant in the innovation expenditure equation. The fact that public financial support is not a significant predictor may be a worry, as it suggests that public funds to promote innovation are not efficiently spent in the Caribbean. Similarly, the insignificance of the "cooperation" variable suggests that spillovers between firms are minimal. In the Crespi-Zuñiga study, exporting was a significant determinant only for Argentina and Colombia. Somewhat surprisingly, in our study, exporting decreases spending on innovation.

\section{The Impact of Innovation Investment on Technological Innovation}

Table 3.10, which presents the estimates of equation 3.16 (the knowledgeproduction functions), shows marginal effects. The results show that the variables "exporter" and "foreign ownership" increase the probability of technological innovation. More specifically, an exporting firm is $48 \%$ more likely to be undertaking innovation, while being foreign-owned increases the probability by 18 percentage points. The fact that foreign firms undertake more innovation, without investing it in the Caribbean, indicates that innovation is probably taking place in the firms' countries of origin. Crespi and Zuñiga (2012) found a similar result only for Chile, where the effect was around $22 \%$. In contrast, to the Crespi-Zuñiga sample, only Colombian exporters were more likely to undertake technological innovation, where the effect is only about a third of what is found for the Caribbean sample.

Caribbean firms, like their Latin American counterparts, are more likely to introduce product or process innovation if they spend more on innovation. More specifically, a unit increase in logged innovation expenditure per employee increases the probability of innovation by 
Table 3.10 Main characteristics of innovative Caribbean firms (\%)

\begin{tabular}{|c|c|c|c|c|c|c|c|c|}
\hline & \multicolumn{2}{|c|}{ Ownership } & \multicolumn{2}{|c|}{ Exporter } & \multicolumn{3}{|c|}{ Size } & \multirow{2}{*}{$\begin{array}{c}\text { Industry } \\
\text { Manufacturing }\end{array}$} \\
\hline & Foreign & Domestic & Exporter & $\begin{array}{l}\text { Non- } \\
\text { exporter }\end{array}$ & Small & Medium & Large & \\
\hline $\begin{array}{l}\text { Antigua and } \\
\text { Barbuda }\end{array}$ & 13 & 87 & 25 & 75 & 50 & 50 & 0 & 100 \\
\hline Bahamas & 33 & 67 & 42 & 58 & 42 & 50 & 8 & 100 \\
\hline Barbados & 19 & 81 & 59 & 41 & 30 & 40 & 30 & 89 \\
\hline Belize & 20 & 80 & 60 & 40 & 27 & 53 & 20 & 100 \\
\hline Dominica & 75 & 25 & 50 & 50 & 0 & 75 & 25 & 100 \\
\hline $\begin{array}{l}\text { Dominican } \\
\text { Republic }\end{array}$ & 15 & 85 & 30 & 70 & 19 & 30 & 41 & 100 \\
\hline Grenada & 29 & 71 & 43 & 57 & 43 & 43 & 14 & 100 \\
\hline Guyana & 20 & 80 & 46 & 54 & 5 & 46 & 49 & 100 \\
\hline Jamaica & 19 & 81 & 31 & 69 & 23 & 35 & 42 & 100 \\
\hline $\begin{array}{l}\text { St. Kitts \& } \\
\text { Nevis }\end{array}$ & 30 & 70 & 50 & 50 & 20 & 50 & 30 & 100 \\
\hline Saint Lucia & 14 & 86 & 29 & 71 & 71 & 29 & 0 & 100 \\
\hline $\begin{array}{l}\text { St. Vincent } \\
\text { \& the } \\
\text { Grenadines }\end{array}$ & 27 & 73 & 53 & 47 & 47 & 40 & 13 & 100 \\
\hline Suriname & 0 & 100 & 33 & 67 & 33 & 58 & 9 & 100 \\
\hline $\begin{array}{l}\text { Trinidad and } \\
\text { Tobago }\end{array}$ & 20 & 80 & 60 & 40 & 20 & 65 & 15 & 100 \\
\hline Total & 25 & 75 & 45 & 55 & 30 & 47 & 23 & 99 \\
\hline
\end{tabular}

Source: Authors' calculations based on WBES data

$56 \%$. The size of the effect is thus higher than that found for all Latin American countries in Crespi and Zuñiga (2012), except for Chile. It appears that spending on innovation has a higher return in terms of product innovation in the Caribbean than most of the countries in Latin America.

\section{The Impact of Innovation on Productivity}

Table 3.11 depicts the results of equation 3.4 (productivity), where the coefficients reported are elasticities or semi-elasticities since the dependent variable is the log of sales per employee. Non-technological innovation has a positive and significant impact on labor productivity, similar to the Crespi-Zuñiga result for Argentina and Colombia, although smaller for the former and somewhat larger for the latter. Caution should be exercised 
Table 3.11 Table of variables

\begin{tabular}{|c|c|c|c|c|}
\hline Variable & Abbreviation & Definition & Mean & St. Dev. \\
\hline Technological innovation & TI & $\begin{array}{l}\text { Dummy equal to } 1 \text { if the } \\
\text { firm introduced product or } \\
\text { process innovation }\end{array}$ & 0.50 & 0.50 \\
\hline $\begin{array}{l}\text { Expenditures on innovation } \\
\text { activities per employee }\end{array}$ & IE & $\begin{array}{l}\text { Log of firm innovation } \\
\text { expenditure divided by } \\
\text { number of employees }\end{array}$ & 8.38 & 2.11 \\
\hline Productivity & Y & $\begin{array}{l}\text { Log of total sales divided by } \\
\text { number of employees }\end{array}$ & 1.61 & 0.61 \\
\hline Firm size & EM & Log of number of employees & 12.10 & 1.40 \\
\hline Exporter/non-exporter & EX & $\begin{array}{l}\text { Dummy variable equal to } 1 \\
\text { if firm exports }\end{array}$ & 0.26 & 0.44 \\
\hline $\begin{array}{l}\text { Non-technological } \\
\text { innovation }\end{array}$ & NTI & $\begin{array}{l}\text { Log of capital investment } \\
\text { divided by number of } \\
\text { employees }\end{array}$ & 1.05 & 0.69 \\
\hline Foreign ownership & $\mathrm{FO}$ & $\begin{array}{l}\text { Dummy variable equal to } 1 \\
\text { if foreign capital above } 10 \%\end{array}$ & 0.17 & 0.34 \\
\hline Patent protection & PA & $\begin{array}{l}\text { Dummy variable equal to } 1 \\
\text { if firm has or filed for patent }\end{array}$ & 0.17 & 0.37 \\
\hline Cooperation & $\mathrm{CO}$ & $\begin{array}{l}\text { Dummy variable equal to } 1 \\
\text { if firm collaborated on } \\
\text { innovation }\end{array}$ & 0.14 & 0.34 \\
\hline Public finance & FIN & $\begin{array}{l}\text { Dummy variable equal to } 1 \\
\text { if firm received public finance } \\
\text { for innovation }\end{array}$ & 0.04 & 0.20 \\
\hline Capital per employee & INV & $\begin{array}{l}\text { Log of capital divided by } \\
\text { number of employees }\end{array}$ & 0.40 & 1.16 \\
\hline
\end{tabular}

Source: Authors' calculations based on WBES data

in reading too much into this result, as we assume that there is no selection bias and no endogeneity for non-technical innovation. Innovation expenditures have a positive and significant impact on labor productivity. The estimated elasticity, 0.63, is larger than for Costa Rica (no effect), Chile (0.60), and Argentina (0.24), but substantially smaller than for Columbia (1.92), Panama (0.8), and Uruguay (0.80).

\section{Concluding Remarks}

In this study we have examined the determinants of spending on innovation and its impact on productivity in the Caribbean. We used a rich cross-sectional enterprise survey covering 14 Caribbean countries with detailed information on innovative activity for manufacturing firms. Our 
analysis showed that there are indeed productivity differences, regardless of the definition of productivity, between innovative and non-innovative manufacturing firms in the Caribbean, although a significant proportion is due to differences in other observable characteristics. More precisely, those firms not spending money on innovation tend to be less productive, although they are also more heterogeneous in their productivity.

We also estimated the determinants of innovation and the causal impact of innovation on productivity in an econometric framework, and compared our results to a previous study done for several Latin American countries. This unearthed a number of interesting results. Specifically, we found that, while there are economies of scope, size appears to be less of an obstacle to undertaking innovation in the Caribbean than in Latin America. The fact that neither having patents nor cooperating with other firms appears to encourage investment is worrisome. Maybe the current legislative framework in the Caribbean does not effectively encourage innovation.

We also discovered that foreign-owned firms are not more inclined than domestically owned firms to invest more in innovation, probably in part because their innovative activities generally take place in their country of origin. Fortunately, it appears that, in the Caribbean, foreign-owned firms nevertheless introduce more innovative techniques than domestically owned ones, thus probably creating the opportunity of spillovers to local firms. Reassuringly, investment in innovation appears to be as successful in the Caribbean as in Latin America in the sense that it translates into introducing new products and processes, not necessarily less than in Latin American countries. Most importantly, we found that new products and processes increase productivity in the region, and that the change may be larger than in some Latin American nations.

More generally, our study showed that the benefits of investing in innovation are not too different than those found for Latin America. Given this, further analysis should investigate what Caribbean firms perceive specifically as obstacles to devoting funds to innovation. Possibilities include insufficient or inefficient legal protection, government support, or inability to compete with foreign firms.

\section{Notes}

1. Other topics include access to finance, gender participation, business-government relations, bribery, trade, capacity utilization, corruption, infrastructure, crime, and competition. 
2. Following Griffith et al. (2006) and Crespi and Zuñiga (2012), an innovative firm is defined as any firm that has taken action to increase its knowledge (i.e. new concepts, ideas, processes, and methods). This includes R\&D expenditures but also spending on other activities related to technological innovation, such as cooperation on innovation activities, receipt of public support for innovation, securing patents, or the purchase of licenses for intellectual property.

3. We chose the other determinants based on data availability and to be in line with our parametric analysis in the "Econometric Model" section of this chapter.

4. For the stochastic productivity component, we assume a half-normal distribution. However, using an exponential distribution instead did not noticeably change our results.

5. We estimate the returns on capital and labor to be 0.18 and 0.89 , respectively, and statistically significant at the $1 \%$ level.

6. The test statistics were $6.97,6.21$, and 4.17 for deterministic productivity, stochastic productivity, and logged labor productivity, respectively.

\section{REFERENCES}

Acemoglu, D., P. Aghion, and F. Zilibotti. 2006. Distance to Frontier, Selection, and Economic Growth. Journal of the European Economic Association 4(1): 37-74.

Aigner, D., C.A.K. Lovell, and P. Schmidt. 1977. Formulation and Estimation of Stochastic Frontier Production Function Models. Journal of Econometrics 6: 21-37.

Arza, V., and A. López. 2010. Innovation and Productivity in the Argentine Manufacturing Sector. Working Paper Series no. IDB-WP-187. Washington, DC: The Inter-American Development Bank (IDB).

Aw, B.Y., M. Roberts, and D. Xu. 2008. R\&D Investments, Exporting, and the Evolution of Firm Productivity. American Economic Review 98(2): $451-456$.

Calvo, J. 2003. The Export Activity of Spanish Manufacturing Firms: Does Innovation Matter? Proceedings of the 43th Congress of European Regional Science Association. August 2003. Finland.

Chudnovsky, D., A. López, and G. Pupato. 2006. Innovation and Productivity in Developing Countries: A Study of Argentine Manufacturing Firms' Behavior (1992-2001). Research Policy 35(2): 266-288.

Cohen, W., and D. Levinthal. 1989. Innovation and Learning: The Two Faces of R\&D. Economic Journal 99(397): 569-596.

Correa, P.I., G. Sánchez, and H. Singh. 2005. Research, Innovation and Productivity: Firm Level Analysis for Brazil. Washington, DC: The World Bank. 
Crépon, B., E. Duguet, and J. Mairesse. 1998. Research, Innovation and Productivity: An Econometric Analysis at the Firm Level. Economics of Innovation and New Technology 7(2): 115-158.

Crespi, G., and P. Zuñiga. 2012. Innovation and Productivity: Evidence from Six Latin American Countries. World Development 40(2): 273-290.

Daude, C., and E. Fernández-Arias. 2010. The Importance of Ideas: Innovation and Productivity in Latin America. In The Age of Productivity: Transforming Economies from the Bottom Up, ed. C. Pages. Washington, DC: Palgrave Macmillan.

Delgado, M., J.C. Fariñas, and S. Ruano. 2002. Firm Productivity and Export Markets: A Non-Parametric Approach. Journal of International Economics 57(2002): 397-422.

DiNardo, J., N. Fortin, and T. Lemieux. 1996. Labor Market Institutions and the Distribution of Wages, 1973-1993: A Semi-Parametric Approach. Econometrica 64(5): 1001-1045.

Felder, J., G. Licht, E. Nerlinger, and H. Stahl. 1996. Factors Determining R\&D and Innovation Expenditure in German Manufacturing Industries. In Determinants of Innovation: The Message from New Indicators, ed. A. Kleinknecht. London: Macmillan.

Freeman, C. 1994. The Economics of Technical Change. Cambridge Journal of Economics 18(5): 463-514.

Griffith, R., E. Huergo, J. Mairesse, and B. Peters. 2006. Innovation and Productivity Across Four European Countries. Oxford Review of Economic Policy 22(4): 483-498.

Griliches, Z. 1979. Issues in Assessing the Contribution of Research and Development to Productivity Growth. Bell Journal of Economics 10(1): 92-116.

Griliches, Z. 1986. Productivity, R\&D, and Basic Research at the Firm Level in the 1970s. American Economic Review 76(1): 141-154.

Griliches, Z., and A. Pakes. 1980. Patents and R\&D at the Firm Level: A First Look. NBER Working Paper no. 561. Cambridge, MA: National Bureau of Economic Research.

Hall, R., and C. Jones. 1999. Why do Some Countries Produce so Much More Output per Worker Than Others? The Quarterly Journal of Economics 114(1): 83-116.

Hall, B., and J. Mairesse. 2006. Empirical Studies of Innovation in the KnowledgeDriven Economy. Economics of Innovation and New Technology 15(4-5): 289-299.

Hegde, D., and P. Shapira. 2007. Knowledge, Technology Trajectories, and Innovation in a Developing Country Context: Evidence from a Survey of Malaysian Firms. International Journal of Technology Management 40(4): 349-370.

IDB. 2010. Science, Technology and Innovation in Latin America and the Caribbean: A Statistical Compendium of Indicators. Washington, DC: IDB.

Jefferson, G., B. Huamao, G. Xiaojing, and Y. Xiaoyun. 2006. R\&D Performance in Chinese Industry. Economics of Innovation and New Technologies 15(40-45): 345-366. 
Lederman, D., J. Messina, S. Pienknagura, and J. Rigolini. 2014. Latin American Entrepreneurs: Many Firms but Little Innovation. Washington, DC: The World Bank.

Lee, K., and S. Kang. 2007. Innovation Types and Productivity Growth: Evidence from Korean Manufacturing Firms. Global Economic Review 36(4): 343-359.

Mairesse, J., and P. Mohnen. 2010. Using Innovation Surveys for Econometric Analysis. NBER Working Paper no. 15857. Cambridge, MA: National Bureau of Economic Research.

Navarro, J.C., J.J. Llisterri, and P. Zuñiga. 2010. The Importance of Ideas: Innovation and Productivity in Latin America. In The Age of Productivity: Transforming Economies from the Bottom Up, ed. Carmen Pages. Washington, DC: IDB and Palgrave Macmillan.

NCST. 2005. Science and Technology for Socio-Economic Development a Policy for Jamaica. Kingston, Jamaica: National Commission on Science and Technology (NCST). Available at http://www.eclac.cl/iyd/noticias/ pais/7/31467/Jamaica_Doc_2.pdf

Nurse, K. 2007. Science, Technology, and Innovation in the Caribbean. Paper presented at Technology Policy and Development in Latin America UNECLAC, Santiago, Chile.

OECD. 2009. Innovation in Firms: A Microeconomic Perspective. Paris, France: Organization for Economic Cooperation and Development (OECD).

Ortiz, E.A., G. Crespi, E. Tacsir, F. Vargas, and P. Zuñiga. 2012. Innovation for Economic Performance: The Case of Latin American and Caribbean Firms. Technical note IDB-TN-494. Washington, DC: IDB.

Pérez, P., G. Dutrenit, and F. Barceinas. 2005. Innovation Activity and Economic Performance: An Econometric Analysis of the Mexican Case. Buenos Aires, Argentina: Indicators of Science and Technology in Latin America. M. Albornoz and D. Ratto (eds.), Indicadores de Ciencia y Tecnología en Iberoamerica. Agenda 2005, 299-318.

Raffo, J., S. Lhuillery, and L. Miotti. 2008. Northern and Southern Innovativity: A Comparison Across European and Latin American Countries. European Journal of Development Research 20(2): 219-239.

Rouvinen, P. 2002. R\&D-Productivity Dynamics: Causality, Lags, and Dry Holes. Journal of Applied Economics 5(1): 123-156.

Schumpeter, J. 1939. Business Cycles: A Theoretical, Historical, and Statistical Analysis of the Capitalist Process. New York: McGraw-Hill.

(c) (1) () $\fallingdotseq$ Except where otherwise noted, this work is licensed under a Creative (c) At ${ }_{\mathrm{BY}} \mathrm{NC}$ ND Commons Attribution-NonCommercial-NoDerivatives 3.0 IGO License. To view a copy of this license, visit https://creativecommons.org/licenses/ by-nc-nd/3.0/igo/ 